"Expectations of individuals regarding the ljara Forward contract: the case of healthcare financing"

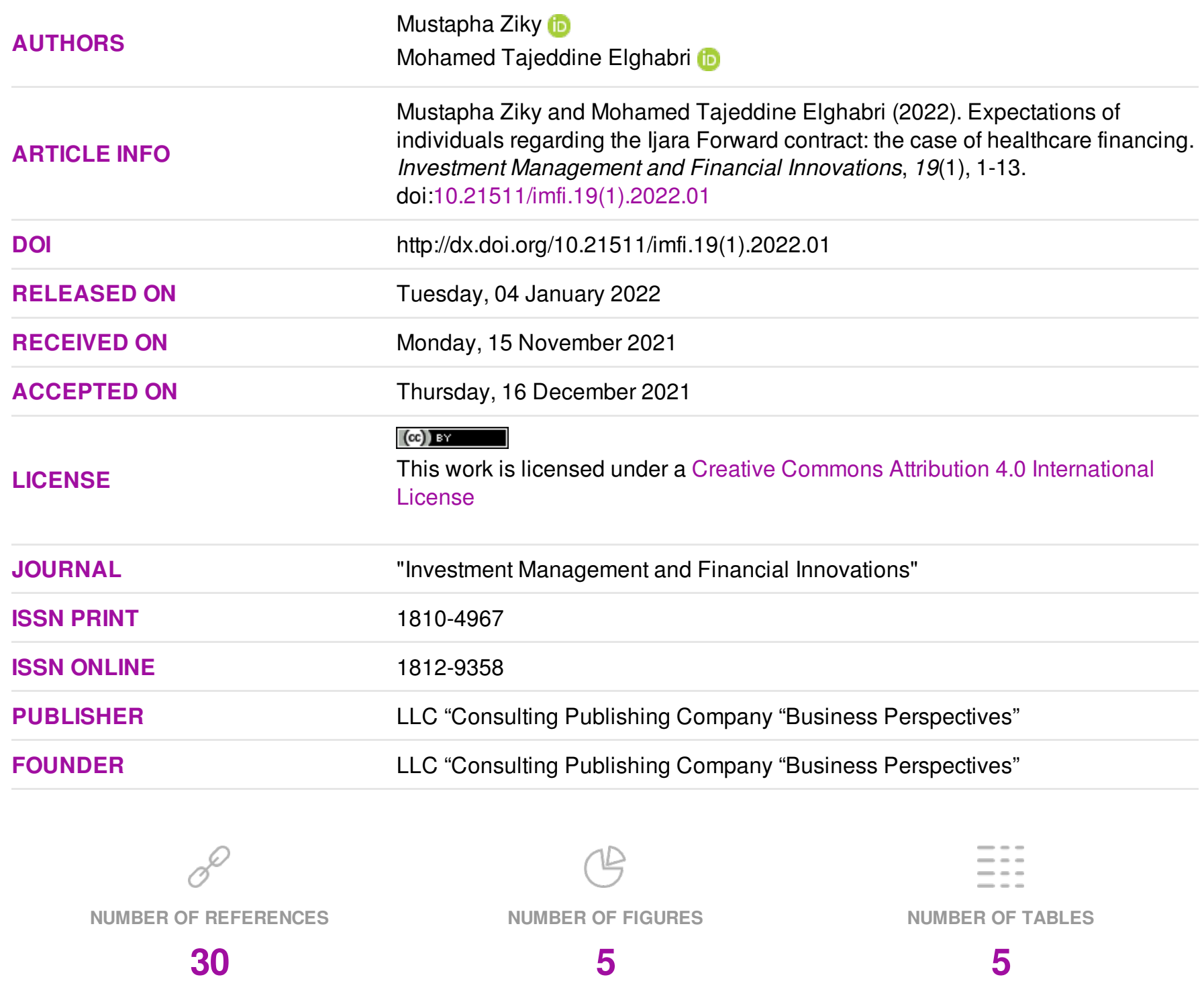

(c) The author(s) 2022. This publication is an open access article. 


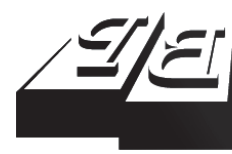

BUSINESS PERSPECTIVES

9

LLC "CPC "Business Perspectives"

Hryhorii Skovoroda lane, 10,

Sumy, 40022, Ukraine

www.businessperspectives.org
Received on: $15^{\text {th }}$ of November, 2021 Accepted on: $16^{\text {th }}$ of December, 2021 Published on: $4^{\text {th }}$ of January, 2022

(C) Mustapha Ziky, Mohamed Tajeddine Elghabri, 2022

Mustapha Ziky, Head of INREDD Research Laboratory, Prof., Department of Economics, Cadi Ayyad University of Marrakech, Morocco.

Mohamed Tajeddine Elghabri, INREDD Research Laboratory, Department of Economics, Cadi Ayyad University of Marrakech, Morocco. (Corresponding author)
Mustapha Ziky (Morocco), Mohamed Tajeddine Elghabri (Morocco)

\section{EXPECTATIONS OF INDIVIDUALS REGARDING THE IJARA FORWARD CONTRACT: THE CASE OF HEALTHCARE FINANCING}

\begin{abstract}
The health sector in Morocco is marked by many achievements, but also by large deficits, especially in terms of healthcare expenditures borne by individuals. With the introduction of Islamic banks (called participative banks) in Morocco, the study aims to determine the extent to which Ijara Forward, as an Islamic financial contract, is adapted to the expectations of Moroccans to finance their health expenditures.

The study sample consisted of 200 individuals. The univariate and bivariate analyses are used to identify possible relationships between the study variables. In addition, this paper proposes a model that will predict the demand for Ijara Forward based on the logistic regression method.

The results reveal that the financial characteristics of the Ijara Forward contract are in line with the financial expectations of Moroccan individuals. Furthermore, the cost of health services is the main factor that makes healthcare inaccessible. This factor influences the demand of Ijara Forward. In addition, this paper reveals that religious beliefs stimulate Ijara Forward's demand and encourages people to pay a higher price for Ijara Forward.
\end{abstract}

\section{Keywords}

Islamic finance, participative banks, personal health finance, logistic regression, Morocco

JEL Classification G00, G21

\section{INTRODUCTION}

The Moroccan health system, a key sector for every society, is significantly marked by insufficient and unsustainable financing (Adaskou et al., 2021). Furthermore, a large proportion of the Moroccan population has limited access to healthcare services (El Alami \& Kherbach, 2008; Belmaati, 2015). In addition, the out-of-pocket expenditure as a percentage of current health expenditure (47\%) is still significantly high (WHO, 2021). Despite the efforts made by the authorities, Moroccan individuals face multiple difficulties to finance their health needs.

The introduction of Islamic finance in Morocco can mobilize substantial funding and new financial products, offering more financial options to individuals who have difficulty accessing the traditional banking system. As such, Islamic banks are well placed to play a key role in financing health services through an appropriate financial instrument - Ijara Forward. It is relevant to study the expectations of individuals regarding the Ijara Forward contract in the case of healthcare financing.

It is important to point out that this study does not intend to find a solution to the problem of health financing but essentially aims to discuss the application of an Islamic financial product suitable for the financing of health expenditures. The Ijara Forward contract is a solution to the problem of liquidity availability and is not a structural source of health financing system such as universal health coverage. 


\section{LITERATURE REVIEW AND HYPOTHESES DEVELOPMENT}

Ijara Forward, as a contract arising from Islamic jurisprudence, figures in the very old legal and Shariatic documentation. The lack of literature on this research topic is explained by the new and innovative nature of the Ijara Forward. From ancient Figh literature, authors have referred to Ijara Forward as a type of Ijara contract (Nawawi, 1991; Al-Minhaji, 1996; Ben Qudama, 1997; Ibn Najjar, 1999; Ibn Muflih, 2003). However, one scholar has a different vision and regards Ijara Forward as a type of Salam financing service (Al-Dasuki, 1910). Ijara Forward is also known as Ijarah $\mathrm{Al}$ Mawsufah Fi Al-Dhimmah.

Contemporary researchers have further developed and discussed the conditions related to Ijara Forward, including Hammad (2007), Kassimi (2009), Mhidat (2010), Al-Buti (2014), Amer and Ninasrin (2012), Mikail (2013), Abu Talib and Akhtarzaite (2015), and Dieng (2019).

It should be noted that this paper do not take a Shariah position on the Ijara Forward contract since the objective is only to discover the way in which it is currently applied in Islamic banks. A famous financial structuring based on the Ijara Forward will be presented in the following (Figure 1).

Furthermore, healthcare costs are increasing. Individuals have less health insurance coverage. As a result, Islamic banks have developed an appropriate method of financing to help their clients overcome the financial barriers that deprive them of access to health services.

A customer who has no liquidity available to finance the service can benefit from this method of financing, since the bank buys, initially, the service described by the customer and resells it to him in exchange for payment in the future, as a lump-sum payment or in installments.

This mode, called Ijara Forward, can be applied to finance medical services. Generally, Ijara Forward's applicant is an indigent patient or a patient in temporary financial difficulty, who will be required to pay for health services in advance.

As such, the Islamic financial institution would be able to use Ijara Forward's formulas to finance health services for the benefit of its clients. The

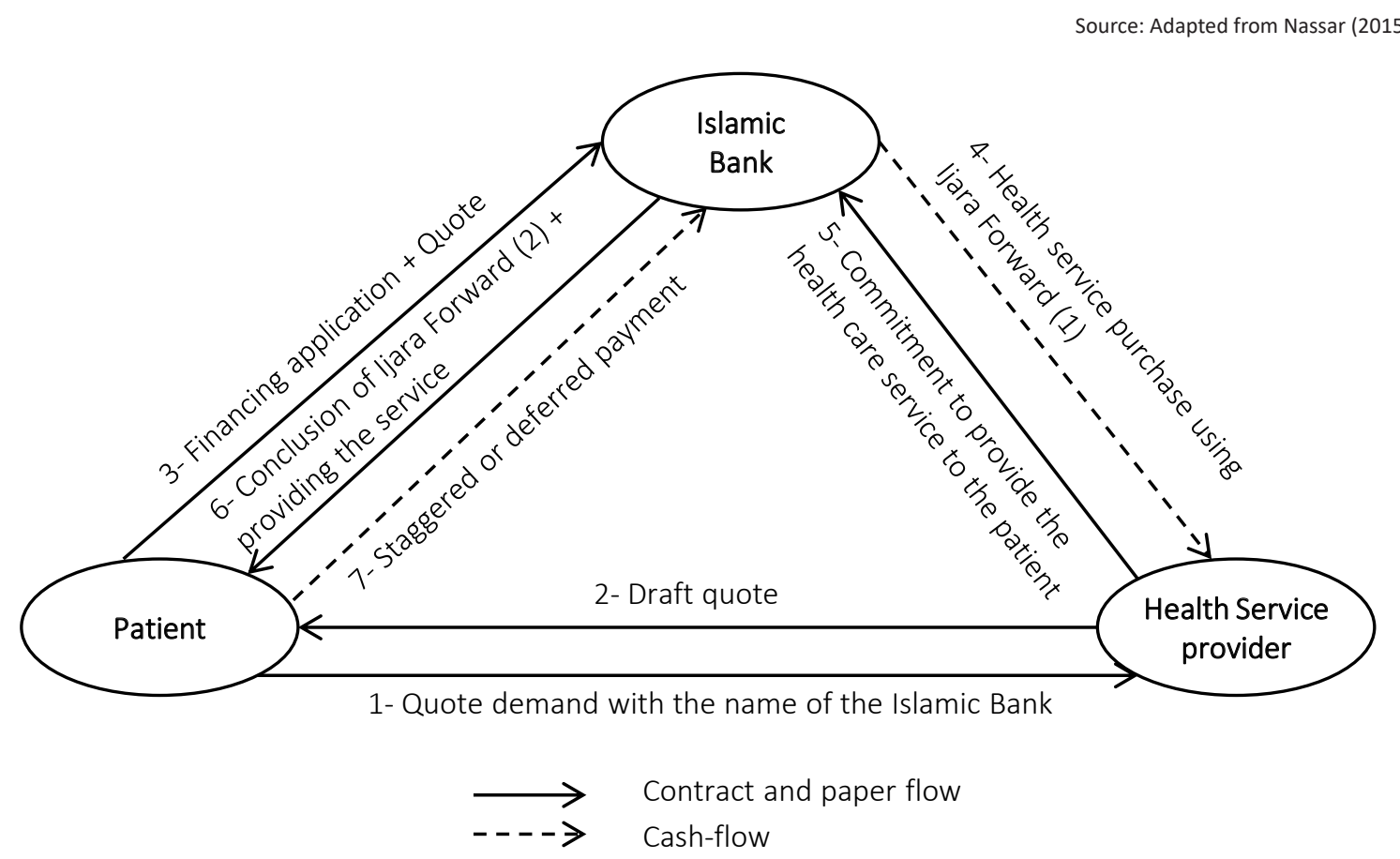

Figure 1. The most used formula for financing health expenditure through ljara Forward 
formula, illustrated below, is widely applied in Islamic banks, such as the Islamic Bank of Abu Dhabi and the Arab Finance Bank (Nassar, 2015).

According to this formula, the client is requested to provide all the necessary elements for the subscription of the Ijara Forward contract (Quote with the name of the Islamic bank, bank statement, payslip, guarantees, etc.). In addition, the bank ensures that the quote describes fully the type of medical procedure and the date of the service.

Once the necessary documents have been gathered and the financial analysis is conducted, the bank begins its administrative process with the health service provider. This leads to the conclusion of an Ijara Forward contract. Thus, the bank and the service provider agree to provide the service in question to the third party (patient) under the contract concluded.

The contractors may agree on a time-limited option, allowing the Islamic bank to execute the option to unilaterally cancel the contract for an agreed period. The option clause allows the bank to exercise its right to end the contract before its execution, since it is a forward contract whose execution is staggered over time.

After concluding the contract with the health service provider, the banking institution enters into another Ijara Forward contract with its service-requesting client. Through this contract, the client will be allowed to benefit from the health services provided by the producer. In addition, the customer will honor its commitments to the bank through a staggered or deferred payment.

Abu Ghuddah (2008) was one of the first researchers to study Ijara Forward in a very particular way. He outlined the Shariah principles that must be observed in this contract. Furthermore, he showed the great importance of Ijara Forward in financing services such as health, education, pilgrimage, and housing.

According to Abu Ghuddah (2009), the Ijara Forward contract can be defined as the lessor's commitment to providing a well-described service, according to the standards required in Salam contract, whether the service relates to an object, such as the rental of a car with certain specifications, or human services, such as sewing or teaching.

Nassar (2009) has developed a comprehensive conceptual framework for the Ijara Forward contract in Islamic jurisprudence. He also attempted to clarify and resolve the dispute over the immediate payment of the rental price.

Kassmi (2009) pointed out that the Ijara may relate either to a particular asset or to an asset described by characteristics that the lessor undertakes to provide. The author states that Islamic financial institutions can finance health services through Ijara Forward, such as medication and the maintenance of medical equipment.

Table 1. Summary of the literature review

\begin{tabular}{|c|c|c|}
\hline Author(s) & $\begin{array}{l}\text { Type of } \\
\text { study }\end{array}$ & Key result(s) \\
\hline $\begin{array}{l}\text { Nawawi (1991), Al- } \\
\text { Minhaji (1996), Ben } \\
\text { Qudama (1997), Ibn } \\
\text { Najjar (1999), Ibn Muflih } \\
\text { (2003) }\end{array}$ & Theoretical & $\begin{array}{l}\text { Ijara Forward is } \\
\text { considered as another } \\
\text { type of Ijara contract }\end{array}$ \\
\hline Al-Dasuki (1910) & Theoretical & $\begin{array}{l}\text { Ijara Forward is } \\
\text { considered a Salam of } \\
\text { services }\end{array}$ \\
\hline $\begin{array}{l}\text { Al-Buti (2007), Hammad } \\
\text { (2007), Kassimi (2009), } \\
\text { Mhidat (2010), Mikail } \\
\text { (2013), Amer and } \\
\text { Ninasrin (2012), and Abu } \\
\text { Talib and Akhtarzaite } \\
\text { (2015) }\end{array}$ & Theoretical & $\begin{array}{l}\text { Discussing } \\
\text { conditions and Fiqh } \\
\text { characterization } \\
\text { related to Ijara } \\
\text { Forward }\end{array}$ \\
\hline Abu Ghuddah (2008) & Theoretical & $\begin{array}{l}\text { Ijara Forward is the } \\
\text { most appropriate } \\
\text { Islamic contract for } \\
\text { financing services such } \\
\text { as health }\end{array}$ \\
\hline Nassar (2009) & Theoretical & $\begin{array}{l}\text { A complete conceptual } \\
\text { framework for the ljara } \\
\text { Forward contract }\end{array}$ \\
\hline Kassmi (2009) & Theoretical & $\begin{array}{l}\text { Islamic financial } \\
\text { institutions have the } \\
\text { possibility to finance } \\
\text { health services through } \\
\text { ljara Forward }\end{array}$ \\
\hline $\begin{array}{l}\text { Al-Jayousi and Al-Shatti } \\
\text { (2014) }\end{array}$ & Empirical & $\begin{array}{l}\text { Ijara Forward meets } \\
\text { the religious and } \\
\text { financial expectations } \\
\text { of Jordanian individuals }\end{array}$ \\
\hline Dieng (2019) & Case study & $\begin{array}{l}\text { Exploring the } \\
\text { applicability of ljarah } \\
\text { Forward in home } \\
\text { financing in Malaysia }\end{array}$ \\
\hline Syaichoni (2020) & $\begin{array}{l}\text { Library } \\
\text { research }\end{array}$ & $\begin{array}{l}\text { Issues on al-ljarah } \\
\text { al-Maushufah fi } \\
\text { al-Dzimmah }\end{array}$ \\
\hline
\end{tabular}


Al-Jayousi and Al-Shatti (2014) conducted an empirical study on the application of the Ijara Forward contract in Islamic banks in Jordan. Their empirical contributions are important.

Al-Jayousi and Al-Shatti (2014) argued that Islamic banks in Jordan can finance a variety of services, including health services. According to the authors, Ijara Forward meets the religious expectations of individuals regarding the suspicion of the Riba. In addition, they demonstrated that the Ijara Forward meets the financial requirements of individuals. In cases of financial difficulty, the Ijara Forward contract is a financial solution that provides a customer with a future service for deferred payment.

The purpose of this study is to identify the expectations of the Moroccan individuals regarding the Islamic financial product, Ijara Forward. The goal is to detect the main factors that can stimulate the potential demand for this financial product.

Two research hypotheses with sub-hypotheses were formulated as follows:

$H_{1}: \quad$ Ijara Forward may meet the expectations of Moroccan individuals in terms of financing health services.

$H_{1 a}$ : The high cost of healthcare service can influence the potential demand for Ijara Forward.

$H_{1 b}$ : The inability to pay cash for the health service may influence the potential demand for the Ijara Forward.

$H_{1 c}$ : The fairness of pecuniary penalties given to charities can influence the potential demand for Ijara Forward.

$H_{1 d}$ : The free rescheduling of the remaining amounts in the case of temporary financial difficulties of the client may influence the potential demand for Ijara Forward.

$H_{1 e}$ : The procedure to replace the original service supplier in the event of non-fulfilment of its commitments may influence the potential demand for Ijara Forward.
$\mathrm{H}_{2}: \quad$ Ijara Forward can meet the religious expectations of Moroccan individuals in terms of financing health services.

$H_{2 a}$ : Religious belief appears to be a stimulus to the potential demand for Ijara Forward.

$H_{2 b}$ : Pending the establishment of Islamic banks by individuals may encourage the potential demand for Ijara Forward.

$\mathrm{H}_{2 c}: \quad$ Moroccan individuals can accept the expensive payment of an Ijara Forward contract to comply with the precepts of the Sharia.

\section{METHODOLOGY}

The research model of this study is presented in Figure 2.

To achieve the objective of this study, it is ideal to conduct a census survey among the targeted population, but this task remains long and very costly. Therefore, it is essential to use a sampling survey. The use of a survey addressed to a sample of the Moroccan population will allow collecting quantitative data on the targeted population.

The survey was conducted in two regions of the Kingdom of Morocco: Marrakech-Safi and Rabat-Salé-Kenitra. Two hundred individuals were interviewed using convenience sampling. This choice is due to the absence of a sampling frame. This study uses a quantitative approach to study the validity of the research hypotheses. Therefore, a direct face-to-face questionnaire was selected as a survey method. This method has several advantages. The interviewee is strongly encouraged to respond seriously. Nonverbal signals, particularly facial expressions, can detect misunderstandings that require the investigator's intervention (Fenneteau, 2015). This type of survey allows direct contact with respondents in several locations (home, office, and public places). The face-to-face questionnaire allowed the researchers to collect information that was better in terms of quality and quantity. The disadvantage of this method is the obligation to travel to meet the interviewees, which is costly. 


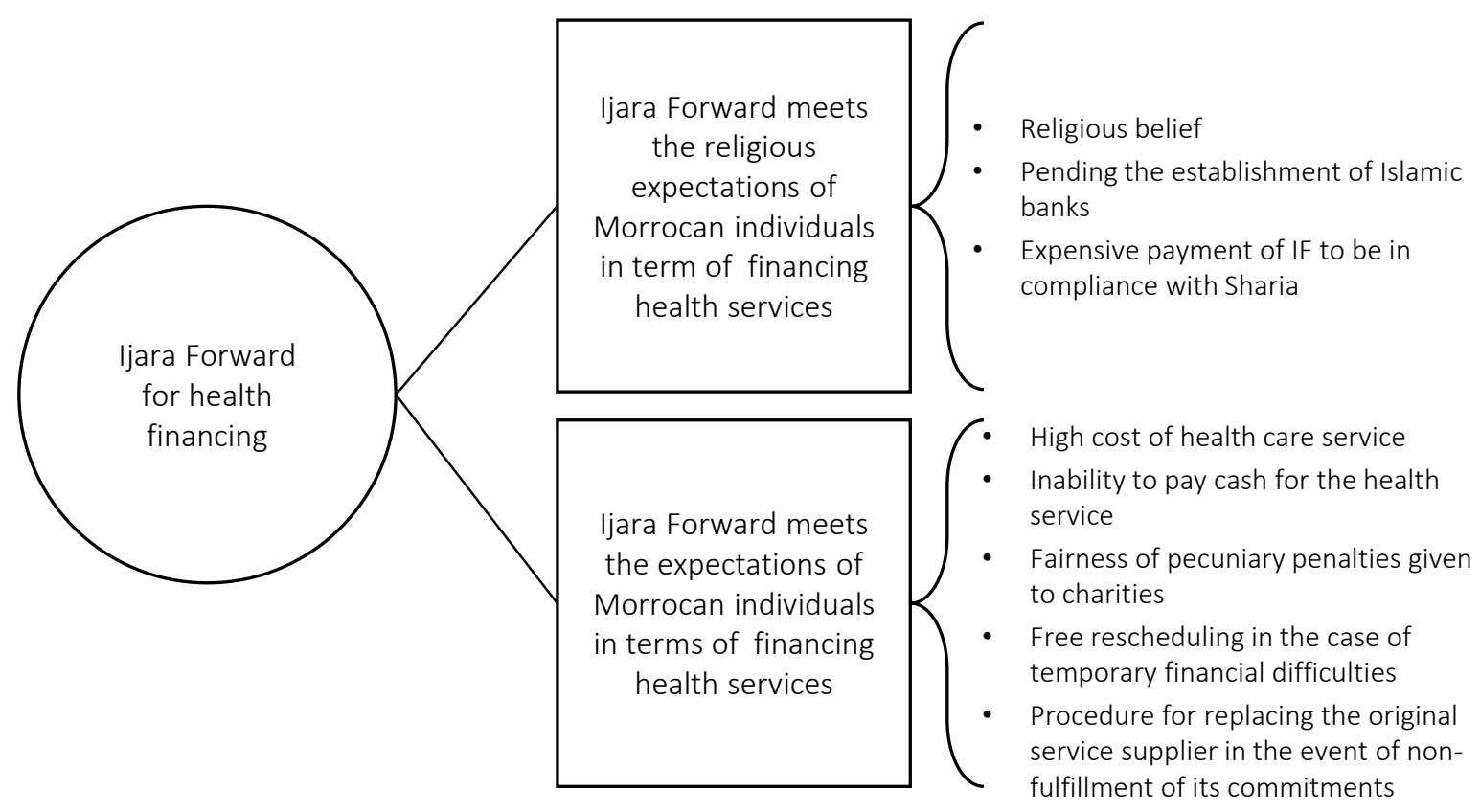

Figure 2. Research model

Regarding the typology of questions, closed-ended questions are chosen. These questions are formulated on a single-choice form (dichotomous or based on a Likert scale) and a multiple-choice form. The questionnaire comprises four main sections. The first section identifies the respondent's social determinants. The second axis examines the degree of satisfaction relating to medical coverage. The third axis studies the financing of health services and its difficulties. The fourth axis focuses on the expectations of individuals regarding the financing of health expenditure through the Ijara Forward contract.

Concerning the analysis of the collected data, this study uses univariate and bivariate analyses to detect possible relationships between the variables to be studied. Then, this paper presents an instrument to predict the demand for healthcare funding through Ijara Forward, developed from a set of explanatory factors that are considered relevant. The objective is to be able to estimate the probability that an individual will or will not apply for Ijara Forward, using the logistic regression model.

Logistic regression is a powerful multivariate analysis tool when the variable to be explained is binary. It allows the modeling of the relationships between the occurrence of any event and each of its associated explanatory factors (Aminot
\& Damon, 2002). Logistic regression is widely applied in epidemiology to detect factors that distinguish healthy people from people with disease. This tool is also used in marketing and finance to predict client behavior.

Through logistic regression, a dichotomous variable $Y$ can be modeled according to explanatory variables $X_{k}=x_{1}, x_{2}, x_{3}, \ldots, x_{k}$

$Y=$ Potential demand of Ijara Forward (variable to be explained).

It is a dichotomous variable whose possible value is 0 (No) or 1 (Yes). $Y=1$ if an individual $(\omega)$ is "potential applicant for Ijara Forward" and $Y=0$ if not. $Y$ follows a Bernoulli distribution of parameters $(\pi)$ with:

$$
\begin{aligned}
& P(Y(\omega) \mid X(\omega)= \\
& =\pi(\omega)^{y(\omega)} \cdot(1-\pi(\omega))^{(1-y(\omega))} .
\end{aligned}
$$

It is noted that $\pi$ is the probability that individual $\omega$ is an applint for Ijara Forward, with:

$\pi(\omega)=P(Y=1 \mid X)=1-P(Y=0 \mid X)$,

where $\pi$ varies in $[0,1]$, and it depends on the values taken by the independent variables. The logistics model suggests expressing $\pi$ as a function of $X_{k}$. 


$$
\begin{aligned}
& \pi(\omega)=\frac{e^{\left(\beta_{0}+\beta_{1} x_{1}+\beta_{2} x_{2}+\ldots+\beta_{k} x_{k}\right)}}{1+e^{\left(\beta_{0}+\beta_{1} x_{1}+\beta_{2} x_{2}+\ldots+\beta_{k} x_{k}\right)}}= \\
& =\frac{1}{1+e^{-\left(\beta_{0}+\beta_{1} x_{1}+\beta_{2} x_{2}+\ldots+\beta_{k} x_{k}\right)}} .
\end{aligned}
$$

Using the Logit function, logistic regression transforms $\pi$ so that it can take its values from $[-\infty,+\infty]$.

$$
\operatorname{Ln}\left[\frac{\pi}{1-\pi}\right]=\beta_{0}+\beta_{1} x_{1}+\beta_{2} x_{2}+\ldots+\beta_{k} x_{k} .
$$

To achieve the objective of developing an instrument to predict the demand for Ijara Forward, this study should follow the steps of modeling using logistic regression. First, construct the model using one of the statistical methods for selecting predictors. Then, test the overall significance of the model. After that, evaluate the quality adjustment. Finally, carry out the diagnosis.

\section{RESULTS}

Figure 3 indicates that $62.5 \%$ of the respondents are male, while women represent $37.5 \%$. In addition, the survey focused on the youth population. Individuals between 31 and 40 years of age are the highest proportion in the survey sample (47\%), followed by the age group between 18 and 30 years $(21.5 \%)$.

Concerning the education level of the respondents, it is noted that almost half of the interviewees (48\%) have a higher level of education, while those with a primary and secondary level represent $27 \%$ and $17 \%$, respectively. Eight percent of the respondents have not received an education. In terms of marital status, $59.5 \%$ of the survey sample are married people and $32 \%$ are single. The proportion of people who are divorced or widowed is relatively low and does not exceed $8.5 \%$ of all respondents.

Most respondents (43\%) are self-employed. The civil servants and the employees constitute successively $20.5 \%$ and $24 \%$ of the survey sample. In addition, most of the interviewees have a monthly income between MAD 2,500 and MAD 4,000.

Furthermore, it is noted that $58.5 \%$ of respondents have health coverage. A total of $44.44 \%$ of them are covered by the AMO-CNOPS (compulsory health insurance for public sector), $32.48 \%$ are covered by AMO-CNSS (compulsory health insurance for private sector), and $20.51 \%$ are covered by RAMED (medical assistance to the economically worst off). A small number of respondents $(2.56 \%)$ are covered by private health insurance.

The study also revealed that a minority of respondents used conventional bank loans to finance their healthcare expenses (4\%). However, the majority of respondents (96\%) do not use conventional loans to finance their healthcare expenses. Large percentages $(87.5 \%)$ of them do not use traditional financing because of religious beliefs.

Furthermore, the survey reveals that $37.5 \%$ of respondents have not sought treatment in the last two years for financial reasons. The high cost of healthcare remains the most common reason, with $81.3 \%$ of responses, followed by other significant reasons such as income instability (56\%), the limitations of the health coverage system (54.7\%), and the inability to pay cash for healthcare (45.3\%).

Concerning the Islamic banking section, more than three-quarters of respondents (77.5\%) are aware of the existence of the Islamic banking industry. While Islamic banks are known to most interviewees, Ijara Forward remains less known.

In addition, the majority of respondents expressed interest in Islamic banking products in general (93.5\%), and in Ijara Forward in particular (95.5\%). Thus, $96 \%$ of individuals are interested in financing their healthcare expenses through the Ijara Forward product. In addition, $91.5 \%$ of respondents expressed their intention to contract the Ijara Forward product in the case of inability to pay cash for medical costs. Furthermore, $96 \%$ of respondents expect that Islamic banks can offer a price similar to the market price of the service in question. The remaining $4 \%$ believe that the Islamic bank will offer the service to the customer with a profit margin compared to the price offered by the supplier.

Concerning the financial cost of the Ijara Forward contract, $64 \%$ of Moroccan individuals expect a lower cost than a traditional bank loan, while 


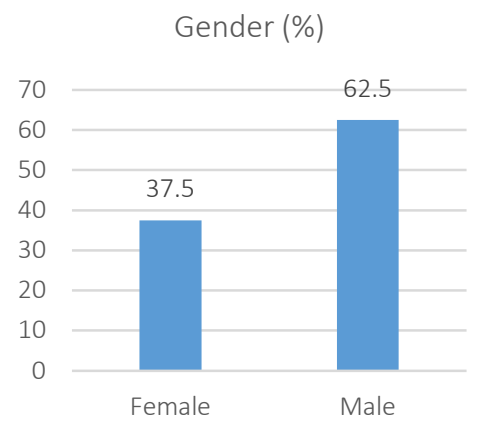

Socio-professional category (\%)

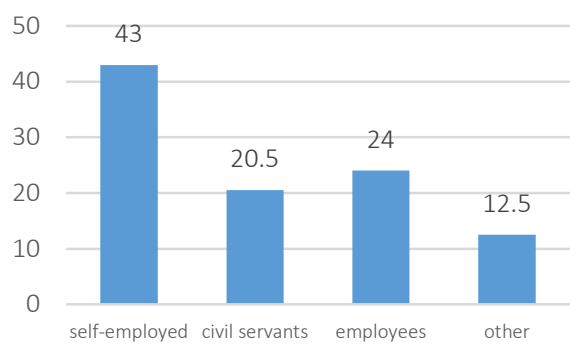

Age (\%)

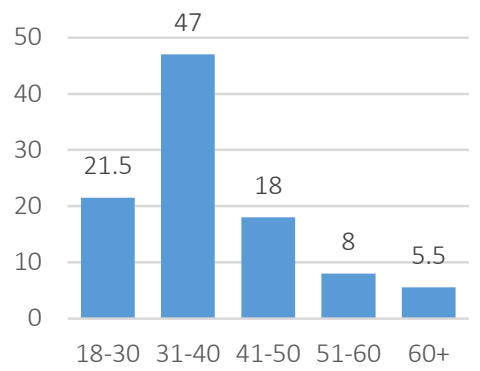

Use of coventional bank loans to finance health care expenses (\%)

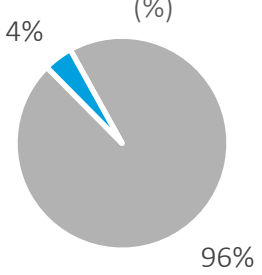

- Yes $\quad$ No

Renouncing health care for financial reasons (\%)

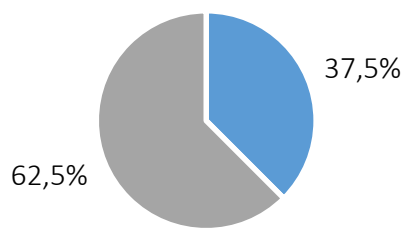

- Yes $\quad \mathrm{No}$
Refusing the traditional banking for religious belief reasons (\%)

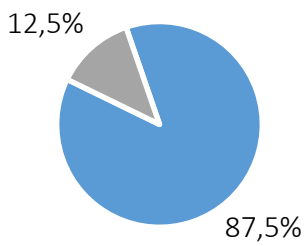

- Yes $-\mathrm{No}$

Awareness of the existence of islamic banking (\%)

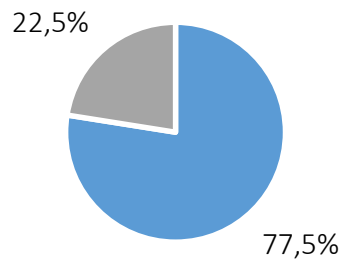

- Yes $=\mathrm{No}$

$7,5 \%$

$7,5 \%$

Figure 3. Preliminary data
Monthly income in MAD (\%)

40

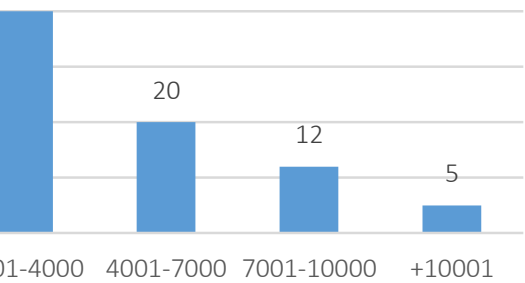

Intention to contract the ljara Forward (\%)

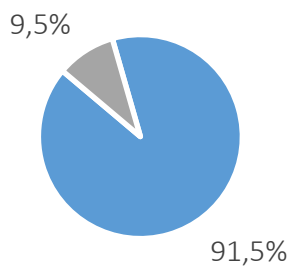

- Yes $\quad$ No
Willingness to pay higher price for ljara Forward (\%)

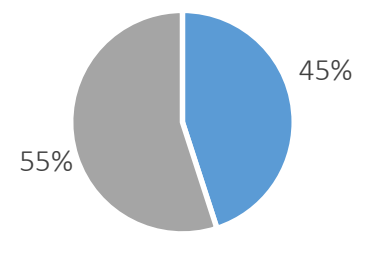

- Yes - No

$31.5 \%$ assume that the costs will be comparable. In addition, the respondents showed great interThe remaining $4.5 \%$ of respondents expect that est in the financial benefits of Ijara Forward. More this product will be expensive compared to a con- than $75 \%$ of the interviewees are satisfied and even ventional health loan. It should be noted that $45 \%$ of respondents are willing to pay a higher price for an Ijara Forward contract. convinced that the Islamic bank would honor its commitments if the service provider did not accomplish the required service promptly. In this 
case, the bank is obliged to find another service provider with the same specific requirements stated in the first contract. Thus, $94.5 \%$ of respondents are motivated by the possible free rescheduling of the remaining amounts in the case of temporary financial difficulties of the bank client, provided he has proven to be in good faith. However, in the event of unjustified late payment, the bank may impose penalties that are then given to charities. More than $60 \%$ of respondents believe that this procedure is fair.

By analyzing the survey results, it should be emphasized that the majority (77.3\%) of respondents wish to ask for Ijara Forward knowing that, in the past, they have given up healthcare services because of their high cost. Moreover, it is noted that the proportion of people seeking Ijara Forward funding increases if the person has already given up seeking treatment because of high healthcare costs.

Thus, it is observed that $90.7 \%$ of individuals wish to obtain financing via Ijara Forward if necessary. Half of these potential clients have already given up seeking treatment because of their inability to pay cash for health services. Moreover, this inability has a positive impact on Ijara Forward's potential demand.
The survey also reveals that the proportion of potential people seeking Ijara Forward increases if a person perceives the formality of applying late penalties for charities as a fair disposition. Thus, the study indicates that a significant proportion of respondents, motivated by the possibility of free rescheduling of the remaining amounts in the case of financial difficulties, express a strong interest in soliciting financial support via Ijara Forward (97.2\%). From the test of independence, it must be pointed out that there is an association between Ijara Forward's potential demand and the level of motivation for possible free rescheduling.

On the other hand, the investigation shows that the attractiveness of the procedure for replacing the original service supplier in the case of non-fulfillment of its obligations does not influence the potential demand for the Ijara Forward product.

In addition, the study reveals that people who have renounced the use of traditional bank loans for religious beliefs are the most likely to apply for healthcare financing through Ijara Forward. In total, it is observed that $82.3 \%$ of respondents want to contract Ijara Forward knowing that they have waived the bank loan because of their religious beliefs. In addition, a positive and statistically moderate association is observed between

Table 2. Hypothesis verification

\begin{tabular}{|c|c|c|c|c|}
\hline \multirow{2}{*}{ Hypothesis } & \multicolumn{2}{|c|}{ Test of independence } & \multirow{2}{*}{$\begin{array}{l}\text { Strength of } \\
\text { relation-ship }\end{array}$} & \multirow{2}{*}{ Verification } \\
\hline & $\chi^{2}$ & $\mathbf{p}$ & & \\
\hline $\begin{array}{l}H_{1 a}: \text { The high cost of healthcare service can influence the } \\
\text { potential demand for ljara Forward }\end{array}$ & 7.528 & 0.02 & 0.317 & Confirmed \\
\hline $\begin{array}{l}H_{10}: \text { The inability to pay cash for the health service may } \\
\text { influence the potential demand for the ljara Forward }\end{array}$ & 6.402 & 0.014 & 0.292 & Confirmed \\
\hline $\begin{array}{l}H_{1 c}: \text { The fairness of pecuniary penalties given to charities } \\
\text { can influence the potential demand for the ljara Forward }\end{array}$ & 8.437 & 0.0224 & 0.205 & Confirmed \\
\hline $\begin{array}{l}H_{1 d}: \text { The free rescheduling of the remaining amounts in } \\
\text { the case of temporary financial difficulties of the client } \\
\text { may have an influence on the potential demand for the } \\
\text { ljara Forward }\end{array}$ & 13.501 & 0.023 & 0.26 & Confirmed \\
\hline $\begin{array}{l}H_{1 e}: \text { The procedure to replace the original service supplier } \\
\text { in the event of non-fulfillment of its commitments may } \\
\text { influence the potential demand for ljara Forward }\end{array}$ & 1.691 & 0.633 & - & Denied \\
\hline $\begin{array}{l}H_{2 a}: \text { Religious belief appears to be a stimulus to the } \\
\text { potential demand for ljara Forward }\end{array}$ & 14.023 & 0.001 & 0.27 & Confirmed \\
\hline $\begin{array}{l}\mathrm{H}_{2 b}: \text { Pending the establishment of Islamic banks by } \\
\text { individuals may encourage the potential demand for ljara } \\
\text { Forward }\end{array}$ & 10.325 & 0.001 & 0.232 & Confirmed \\
\hline $\begin{array}{l}\mathrm{H}_{2 \mathrm{c}}: \text { Moroccan individuals can accept the expensive } \\
\text { payment of an ljara Forward contract to comply with the } \\
\text { precepts of the Sharia }\end{array}$ & 16.257 & 0.0001 & 0.291 & Confirmed \\
\hline
\end{tabular}


Table 3. Variables included in the binary logistic regression analysis

\begin{tabular}{|c|c|}
\hline Qualitative Variables & Denomination \\
\hline Age & Age range \\
\hline RB & Religious belief \\
\hline Pen_IB & Pending the establishment of Islamic banks \\
\hline Lowlnc & Low income \\
\hline Costh & High Cost of health care service \\
\hline Cash & Inability to pay cash the health care service \\
\hline Int_IB & Interest to contract Islamic banking products \\
\hline Int_IF & Interest to contract ljara Forward to finance services \\
\hline Int_Health & Interest to contract ljara Forward to finance health expenditure \\
\hline Exp_IF & Expensive ljara Forward \\
\hline Penalities & Degree of fairness of penalties for late payment \\
\hline Resched & Free rescheduling of amounts due in case of financial difficulties \\
\hline
\end{tabular}

Ijara Forward's potential demand and religious belief. The higher the proportion of people who reject borrowing because of religious beliefs, the higher the proportion of people who would apply for financing through Ijara Forward. The study also demonstrates a positive association between refusing the traditional loans pending the establishment of Islamic banks in the country and Ijara Forward's potential demand.

Finally, it is noted that many individuals are willing to pay a higher price for an Ijara Forward contract. This represents $42.2 \%$ of all respondents. The majority of them do not use bank loans for religious beliefs. Thus, the higher the proportion of people who renounce bank borrowing for religious belief, the higher the proportion of people who are willing to pay a higher price for an Ijara Forward contract.

Before proceeding with the development of the prediction instrument, it is necessary to select a set of variables by performing bivariate analyses (Khan \& Rebelo, 2019). The goal is to identify potential predictors and eliminate redundant variables or variables that are not related to the dependent variable (Bernard \& Lapointe, 1998; Desjardins, 2007). After a test of independence, a selection of independent variables, associated with the dependent variable "potential demand for Ijara Forward", was made for the logistic regression.

First, the logistic regression model is made using a technique that automatically selects a subgroup of variables based on tests of significance. The model opted for the Forward stepwise selection method is based on the likelihood ratio test.
The result of the automatic selection resulted in three candidate variables to integrate the final model. The likelihood ratio test shows that the three explanatory variables contribute significantly to the model. Tests of dependence between the three explanatory variables reveal that the Resched variable has a strong relationship with the other two explanatory variables. $R B$ and $\operatorname{Cost} H$ are two independent variables. As a result, the progressive inclusion of the variables resulted in a final model that includes the most significant predictors, namely " $R B$ and Cost $H$ " (Table 4).

Table 4. Coefficients of the final logistic regression model

\begin{tabular}{c|c:c}
\hline Constant & RB & Cost $\boldsymbol{H}$ \\
\hline-1.475 & 3.995 & 2.69 \\
\hline
\end{tabular}

Table 5. Overall significance test and evaluation of the regression

\begin{tabular}{c:c}
\hline $\boldsymbol{P}$-value & $\boldsymbol{R}^{2} \mathbf{m f}$ \\
\hline 0.000029 & 0.783 \\
\hline
\end{tabular}

Thereafter, a test of the overall significance of the model was made by detecting the simultaneous influence of the explanatory variables on the variable to be explained via the likelihood ratio test. After that, the p-value, with two degrees of freedom between the trivial model and the final model, was calculated. According to Table 5, this regression model has significant independent variables $(p-$ value $=0.00029<0.05)$. Thus, the explanatory variables $R B$ and $C o s t H$ simultaneously influence the probability to demand Ijara Forward. 


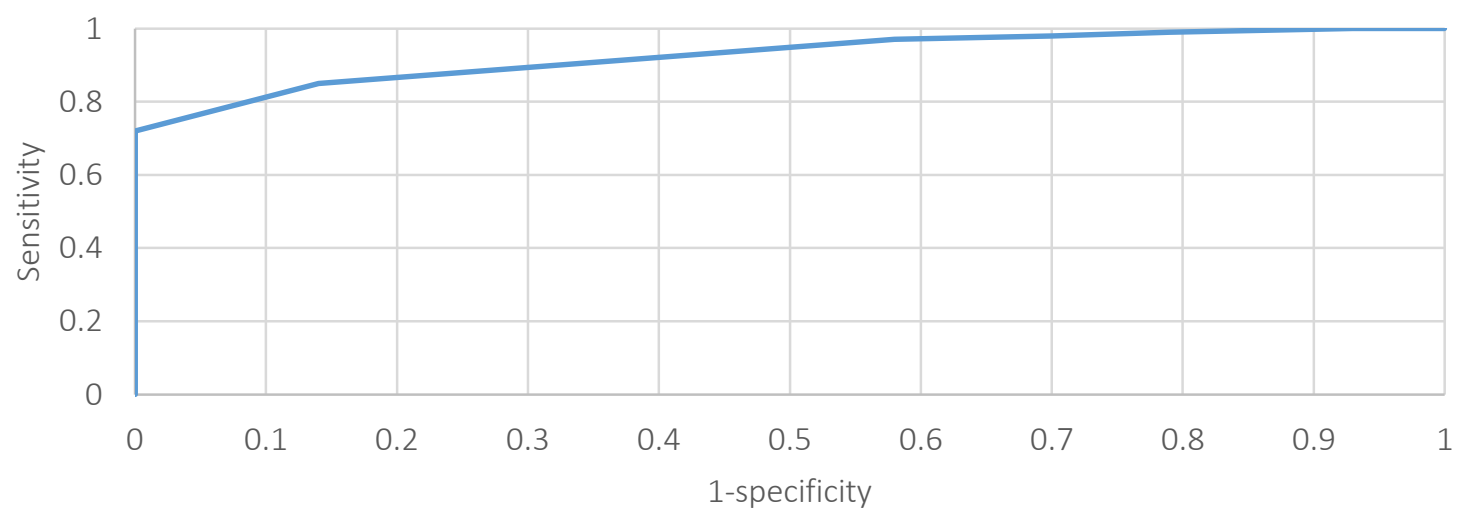

Figure 4. ROC curve

In addition, evaluating the fit of the model based on pseudo- $\mathrm{R}^{2}$ is an important step to evaluate the quality of the fit of the model. These measures quantify the involvement of predictors in explaining the independent variable. McFadden's pseudo- $\mathrm{R}^{2}$ is the most suitable for logistic regression (Menard, 2001). When observing Table 5, the $\mathrm{R}^{2}$ of McFadden indicates a figure of 0.783 . This implies that the final model differs from the model reduced to the constant. Therefore, it is deduced that the overall significance of the model is good by explaining $78.3 \%$ of the variance of the dependent variable "potential demand of Ijara Forward".

Another measure often used to assess the goodness fit of a logistic regression model is the "Receiver Operating Characteristic" curve. Figure 4 illustrates the ROC curve. The area under the red curve is 0.93 . This indicates that the model makes a strong distinction between the two categories that constitute the target variable (potential demand of Ijara Forward). In other words, the fit quality of the model is very good.

After following these steps, the predictive model of Ijara Forward's demand is as follows:

$$
\begin{aligned}
& \operatorname{Logit}[P(Y=1 \mid R B, \operatorname{Cos} t H)]= \\
& =-1.475+3.995 R B+2.69 \operatorname{Cos} t H .
\end{aligned}
$$

In order to interpret the coefficients $\beta i$ of the dichotomous explanatory variables of the model, the odds ratio must be calculated.

The model (Figure 5) shows that people who refuse to take out traditional bank credit for religious beliefs $\left(O R_{\beta 1}=54.315\right)$ and who have given up on medical care because of the high cost of health care service $\left(O R_{\beta 2}=14.74\right)$ are more susceptible to adopt an Ijara Forward product to finance their health expenditures.

\section{DISCUSSION}

This study demonstrates that the Ijara Forward contract meets the financial expectations of Moroccan individuals regarding the financing of health expenditure. This partially confirms the first hypothesis of this study.

This ability of the Ijara Forward contract to meet people's expectations is explained by several facts.

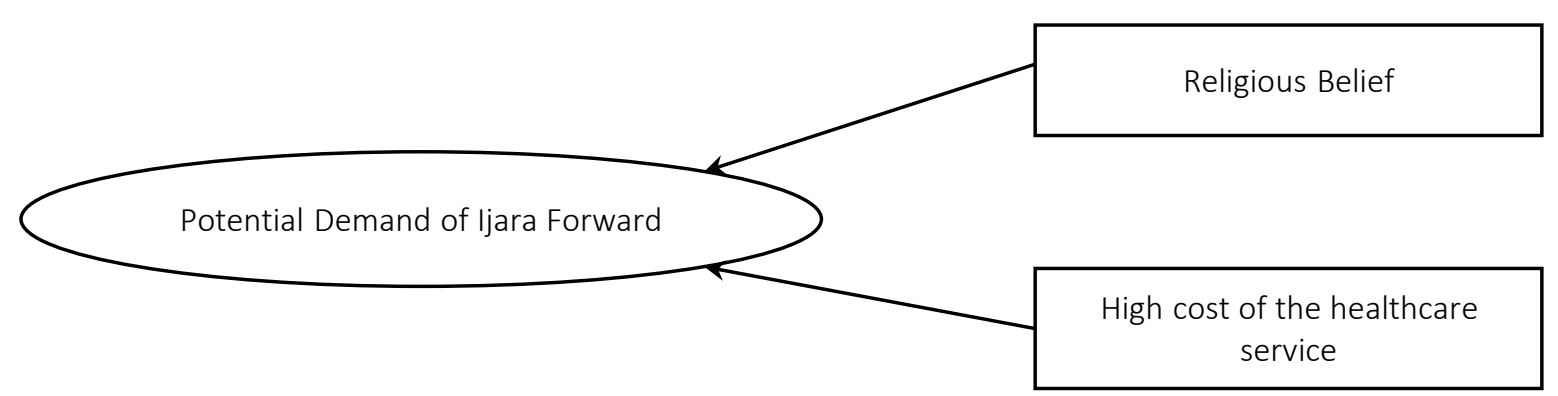

Figure 5. Final model 
First, the high cost of healthcare services and the inability to pay for them in cash are two phenomena that prevent a large proportion of individuals from accessing health services. In addition, the study affirms that these two phenomena influence the potential demand for the Ijara Forward to finance health expenditure $\left(H_{1 a}\right.$ and $\left.H_{1 b}\right)$. This result is in accordance with the findings of Al-Jayousi and Al-Shatti (2014). Indeed, these authors consider Ijara Forward as a real solution to reduce the individual's monthly financial burden and to solve the problem of inability to pay cash for health expenses.

Secondly, the financial characteristics of the Ijara Forward contract are in line with the financial expectations of Moroccan individuals. A customer in financial difficulty can benefit from a free rescheduling of the remaining amounts due. Moreover, even if the bank penalizes financially a recalcitrant customer, it distributes these funds for charitable purposes. However, currently, this feature is not applied by Moroccan Islamic banks. Moreover, the bank is always committed to providing the service even if the original supplier fails to meet its commitments. This study reveals that these formalities attract individuals and influence Ijara Forward's potential demand $\left(H_{1 c}\right.$ and $H_{1 d}$ ), except for the last formality concerning the bank's commitment to providing the service in the case of the original supplier failing to honor its commitments, which does not have a significant influence on the potential demand for the Ijara Forward contract $H_{1 e^{*}}$.

These results partially confirm the results obtained by Al-Jayousi and Al-Shatti (2014). These authors have shown that, in the event of justified financial difficulties, an Islamic bank provides its client with great financial flexibility by spreading payment deadlines free of charge. This option is available in Moroccan Islamic banks, but under specific conditions.

The results also show that the Ijara Forward contract meets the religious expectations of Moroccan individuals regarding the financing of health services. In light of this result, the second hypothesis is confirmed. This is explained by the influence of religious belief and the pending establishment of Islamic banks on Ijara Forward's potential demand $\left(H_{2 a}\right.$ and $\left.H_{2 b}\right)$. The Ijara Forward contract is clearly a financial alternative in harmony with the religious conviction of Moroccan individuals.

Furthermore, a large proportion of individuals are willing to pay a higher price for an Ijara Forward contract. This behavior is explained by their desire to respect the precepts of the Shariah $\left(H_{1 c}\right)$. These results reaffirm those obtained by Al-Jayousi and Al-Shatti (2014) and Nassar (2015). According to them, the Ijara Forward meets the religious beliefs of people rejecting usury.

The study also attempts to partially explain, or even predict, the demand for Ijara Forward through logistic regression. The model derived from this paper's analysis predicts Ijara Forward's demand via two predictors: religious belief and the high cost of healthcare service. In other words, if a person did not use conventional loans for religious beliefs and renounced healthcare because of its high cost, they would be willing to adopt the Ijara Forward contract. In sum, the Ijara Forward contract meets the financial and religious expectations of Moroccan individuals.

\section{CONCLUSION}

This paper aims to detect the expectations of Moroccan individuals regarding the Islamic financial product Ijara Forward. The objective of this study is to answer two fundamental questions. The first question is whether the Ijara Forward contract, designed to finance healthcare expenditures, can meet financial expectations of Moroccan individuals. The second one is to determine whether the Ijara Forward contract can be a financial alternative in harmony with the religious beliefs of Moroccan individuals.

Indeed, the study reveals that the Ijara Forward contract meets the financial expectations of Moroccan individuals. This is confirmed by several facts. First, the high cost of healthcare services and the inability to pay it in cash influence Ijara Forward's potential demand. Second, the financial characteristics 
of the Ijara Forward contract (the possibility of free rescheduling and penalties being paid to charities) match the financial expectations of Moroccan individuals and influence the potential demand for this contract.

The study also found that the Ijara Forward contract is a financial alternative in harmony with the religious beliefs of Moroccan individuals. This is confirmed by the association between the non-use of classic loans for religious beliefs and Ijara Forward's potential demand, on the one hand, and between the pending establishment of Islamic banks and Ijara Forward's potential demand, on the other hand. Another result mentioned in this study indicates that many Moroccan individuals are willing to pay a higher price for an Ijara Forward contract. This behavior is justified by their rejection of usury.

These results are supported by multivariate analysis using logistic regression. Indeed, the predictive model resulting from logistic regression proves that religious belief and high healthcare costs are the factors associated with Ijara Forward's potential demand.

The findings of this study have important implications. The predictive model would help Islamic banks to identify their potential customers in the case of Ijara Forward for health financing. However, these banks should adapt their offer to the needs of their clients, taking into consideration the social aspect of this mode of financing. More efforts are needed to minimize the cost of Ijara Forward financing. It is suggested that Islamic banks enter partnerships with healthcare institutions. Furthermore, to ease the patient's bill, policymakers must support and provide tax advantages to the Ijara Forward's contractors.

\section{AUTHOR CONTRIBUTIONS}

Conceptualization: Mustapha Ziky, Mohamed Tajeddine Elghabri.

Data curation: Mustapha Ziky, Mohamed Tajeddine Elghabri.

Formal analysis: Mustapha Ziky, Mohamed Tajeddine Elghabri.

Investigation: Mustapha Ziky, Mohamed Tajeddine Elghabri.

Methodology: Mustapha Ziky, Mohamed Tajeddine Elghabri.

Project administration: Mustapha Ziky, Mohamed Tajeddine Elghabri.

Resources: Mustapha Ziky, Mohamed Tajeddine Elghabri.

Software: Mustapha Ziky, Mohamed Tajeddine Elghabri.

Supervision: Mustapha Ziky, Mohamed Tajeddine Elghabri.

Validation: Mustapha Ziky, Mohamed Tajeddine Elghabri.

Visualization: Mustapha Ziky, Mohamed Tajeddine Elghabri.

Writing - original draft: Mustapha Ziky, Mohamed Tajeddine Elghabri.

Writing - review \& editing: Mustapha Ziky, Mohamed Tajeddine Elghabri.

\section{REFERENCES}

1. Abu Ghuddah, A. (2008, July). Tamwil Al-manafiaa bi-europa. Paper presented at the 18th session of the European Council for Fatwa and Research, Paris, France. (In Arabian). Retrieved from https:// iefpedia.com/arab/?p=34035

2. Abu Ghuddah, A. (2009, August). Practical applications of Al-Ijarah Al-Mawsufah fi Al-Dhimmah (Forward Ijara). Paper presented at the 30th Al Baraka Annual
Islamic Symposium, Jeddah, Saudi Arabia. Retrieved from http://www. iefpedia.com/english/wp-content/ uploads/2009/10/Practical-Application-of-al-Ijarah-al-Mawsufah-fial-Dhimmah-Forward-Ijarah.pdf.

3. Abu Talib, M. M., \& Akhtar Zaite, A.A. (2015). Dispute over the legality of Al-Ijarah al-Mawsufah fi al-dhimah: A survey of fiqhi opinions. ISRA International Journal of Islamic Finance, 7(1), 49-73.
Retrieved from http://eprints. um.edu.my/16831/

4. Adaskou, M., Houmam, I., \& Onbouh, H. (2021). Demand and supply of health care: advances and theoretical models. International Journal of Accounting, Finance, Auditing, Management and Economics, 2(3), 66-85. https://doi. org/10.5281/zenodo.4785353

5. Al-Buti, M. (2014). Al-Ijara mawsufa fi-dhimma. (In Ara- 
bian). Retrieved from https:// naseemalsham.com/uploads/ Component/word\%20new/Arabic/ Research/2014/Al_Eijara_Al_Mawosoofa_Fi_Al_Zima.pdf.

6. Al-Dasuki, S. (1910). Hachiat addasuki Ala charh al-kabir. Cairo: Attakadum Alilmia. (In Arabian).

7. Al-Jayousi, A., \& Al-Shatti, A. (2014). Tamwil al-manafiaa wa al-khadamat fi al-moassassat al-masrifia al-islamia al-ordonia. Muthanna Journal of Administrative and Economic Sciences, 4(8), 56-76. (In Arabian). Retrieved from https://www.iasj.net/iasj/ article/92791

8. Al-Minhaji, S. (1996). Jawahir al-oukoud wa moaain al-kodat wa al-mowakiaain wa chohoud. Beirut: Dar Al-koutoub alilmia. (In Arabian).

9. Amer, K. M., \& Ninasrin, R. (2012, November). Innovation In Islamic Banking: The Practical Application Of Forward Ijarah And Its Issues And Challenges. Paper presented at The 2nd ISRA Colloquium, Kuala Lumpur, Malaysia. Retrieved from https://nanopdf.com/download/ innovation-in-islamic-bankingislamic-finance-knowledge-repository_pdf

10. Aminot, I., \& Damon, M. (2002). Régression logistique: intérêt dans l'analyse de données relatives aux pratiques médicales. Revue médicale de l'assurance maladie, 33(2), 37-143. (In French). Retrieved from http://bdsp-ehesp.inist.fr/ vibad/index.php?action=getRecor dDetail\&idt $=253424$

11. Belmaati, H. (2015). Le Rôle de l'assurance maladie obligatoire dans le financement des soins de santé au Maroc: état des lieux et perspective d'évolution. Revue Économie, Gestion et Société, 4, 1-18. (In French). https://doi. org/10.48382/IMIST.PRSM/regsv0i4.4178

12. Ben Qudama, M. (1997). Al-Kaffi. Giza: Dar Hajar.

13. Bernard, J., \& Lapointe C. (1998). Mesure statistique en épidémiologie. Quebec: Presse de l'Université du Québec. (In French).

14. Desjardins, J. (2005). Lanalyse de régression logistique. Tuto- rial in Quantitative Methods for Psychology, 1(1), 35-41. (In French). https://doi.org/10.20982/ tqmp.01.1.p035

15. Dieng, M. M. (2019). The Applicability of Ijarah Al-Mawsufah Fi Al-Dhimmah in Malaysia. International Journal of Management and Applied Research, 6(4), 196-207. https://doi. org/10.18646/2056.64.19-014

16. El Alami, E. A., \& Kherbach, F. (2008). Etude sur le financement des soins de sante au maroc. (In French). Retrieved from http:// www.albacharia.ma/xmlui/handle/123456789/31081

17. Fenneteau, H. (2015). L'enquête: entretien et questionnaire. Paris: Dunod. (In French).

18. Hammad, H. (2007). Sukuk Ijara. Damascus: Dar Alkalam.

19. Ibn Muflih, S. (2003). Kitab Alforoaa. Beirut: Arrissala nachiron.

20. Ibn Najjar, T. (1999). Muntaha al-iradat. Beirut: Arrissala nachiron.

21. Kassimi, B. (2009, June). AlIjara al-mawsufa fi dhimma lil-khadamat ghayr al-moaayyana. Paper presented at the Congress of Islamic Affairs and Charitable Activities Department on Islamic banks between practices and theoretical issues, Dubai, United Arab Emirates. (In Arabian). Retrieved from https://iefpedia.com/ $\operatorname{arab} / ? \mathrm{p}=2850$

22. Khan, Y. H., \& Rebelo, E. (2019). Better infrastructure, amazing climate, unique price and marketing: have travelers on your side. Tourism and Travelling, 2(1), 8-15. http://dx.doi.org/10.21511/ tt.2(1).2019.02

23. Menard, S. (2001). Applied Logistic Regression Analysis. Thousand Oaks, CA: SAGE.

24. Mhidat, F. (2010). Al-Ijara fi-dhimma. (In Arabian). Retrieved from https://iefpedia.com/ $\mathrm{arab} / ? \mathrm{p}=13040$

25. Mikail, S. A. (2013). The Fiqh Characterization of Ijārah Mawșūfah fī Al-Dhimmah: An Analysis of Juristic Views. ISRA International Journal of Islamic
Finance, 5(2), 169-176. https://doi. org/10.12816/0002777

26. Nassar, A. (2009). The Parameters of Forward Ijarah and its Application in Financing Services in Islamic Financial Institutions. Retrieved from https://www.academia. edu/235360/The_Parameters_of_ Forward_Ijarah_and_its_Application_in_Financing_Services_in_ Islamic_Financial_Institutions

27. Nassar, A. (2015). Tamwil al-khadamat fi almasarif al-islamia bistikhdam sighat al-Ijara Mawsufa fi Dhimma. Beirut: Dar Al-koutoub alilmia. (In Arabian).

28. Nawawi, M. (1991). Rawdat attalibin wa omdat al-moftine. Amman: Almaktab alislami.

29. Syaichoni, A. (2020). Al-Ijarah Al-Maushufah fi Al-Dzimmahin the Study of Islamic Financial Economics. Economica: Jurnal Ekonomi Islam, 11(2), 309-328. https://doi.org/10.21580/economica.2020.11.2.6834

30. World Health Organization (WHO). (2021). Global Health Observatory (GHO) data. Retrieved from https://www.who.int/data/ gho/data/indicators/indicator-details/GHO/out-of-pocket-expenditure-as-percentage-of-currenthealth-expenditure-(che)-(-) 